\title{
Activation of AKT/PKB in breast cancer predicts a worse outcome among endocrine treated patients
}

\author{
G Pérez-Tenorio*,1, O Stål' and members of the Southeast Sweden Breast Cancer Group ${ }^{2}$ \\ 'Department of Biomedicine and Surgery, Division of Oncology, Clinical Research Center, Faculty of Health Sciences, Linköping University, SE-58I 85 Linköping, \\ Sweden
}

Akt/PKB is a serine/threonine protein kinase that regulates cell cycle progression, apoptosis and growth factor mediated cell survival in association with tyrosine kinase receptors. The protein is a downstream effector of erbB-2 with implications in breast cancer progression and drug resistance in vitro. We aimed to examine the role of Akt-I in breast cancer patients, by determining whether the expression (Akt-I) and/or activation (pAkt) were related to prognostic markers and survival. The expression of erbB-2, heregulin $\beta 1$ and $\mathrm{Bcl}-2$ was also assessed by flow cytometry or immunohistochemistry. This study comprised 93 patients, aged $<50$ who were treated with tamoxifen and/or goserelin. We found that pAkt was associated with lower S-phase fraction $(P=0.00 I)$ and the presence of heregulin $\beta \mid$-expressing stromal cells $(P=0.017)$. Neither Akt-I nor pAkt was related with other factors. Tumour cells-derived heregulin $\beta \mid$ was found mainly in oestrogen receptor negative $(P=0.026)$ and node negative $(P=0.005)$ cases. Survival analysis revealed that pAkt positive patients were more prone to relapse with distant metastasis, independently of $S$-phase fraction and nodal status (multivariate analysis; $P=0.004$ ). The results suggest that activation of Akt may have prognostic relevance in breast cancer.

British Journal of Cancer (2002) 86, 540 -545. DOI: 10.1038/sj/bjc/6600I26 www.bjcancer.com

(C) 2002 Cancer Research UK

Keywords: breast cancer; endocrine treatment; Akt; PKB; erbB-2; heregulin $\beta$ ।

Endocrine therapy remains the most used systemic treatment in breast cancer. The presence of oestrogen receptor (ER) is the guide in the therapeutic decision. Complete oestrogen blockade seems to be more effective compared with single agent endocrine treatment. Combined therapy, involving luteinizing hormone-releasing hormone (LHRH) analogues such as goserelin (Zoladex) and tamoxifen has been employed to reduce oestrogen levels and to prevent the oestrogenic activity at the cellular level (Michaud and Buzdar, 2000). However in spite of higher response rate, tumour resistance to endocrine treatments develops over time and constitutes a critical problem (MacGregor and Jordan, 1998; Clarke et al, 2001).

Anti-oestrogen resistance may be explained by several mechanisms, including loss or mutation of ER, increased estradiol level, alterations in anti-oestrogen metabolism or interactions between growth factor receptors and ER cascades (reviewed in Clarke et al, 2001). These mechanisms, mainly involved in cell proliferation, may coexist with those affecting cell death. Increasing amount of evidence indicates that the mechanisms whereby drugs such as the LHRH analogues and tamoxifen exert the cytotoxic action also include apoptosis (Perry et al, 1995; Imai and Tamaya, 2000). Therefore, factors involved in the apoptotic failure may also contribute to the anti-oestrogen resistance.

Recently, the phosphatidylinositol $3^{\prime}$ kinase (PI3K)/Akt cascade, which is the major survival pathway for many cell types, has been

*Correspondence: G Pérez-Tenorio; E-mail: gizpe@ibk.liu.se

${ }^{2}$ Members of the Southeast Sweden Breast Cancer Group are listed at the end of this study.

Received I8 May 200I; revised 3 December 200 I; accepted 5 December 2001 related to activation of $\mathrm{ER}$ in vitro and with protection from tamoxifen-induced apoptosis (Campbell et al, 2001).

Akt, also called protein kinase B (PKB), is the cellular homologue of the vAkt oncogene found in the highly transforming retrovirus AKT8 (Ahmed et al, 1993). Human Akt exists as three closely related isoforms: Akt-1/PKB $\alpha$, Akt-2/PKB $\beta$ and Akt-3/PKB $\gamma$. Akt-1 is activated by phosphorylation on two critical residues: threonine 308 in the kinase domain and serine 473 in the C-terminal tail. The active protein (pAkt) is a downstream effector of the growth factor-stimulated PI3K (Coffer et al, 1998) and may contribute to the genesis of cancer by blocking programmed cell death (Kandel and Hay, 1999).

From in vitro studies it is known that induction of cell survival by Akt isoforms affects signalling cascades triggered by a wide range of receptors. Platelet-derived growth factor (PDGF) (Klinghoffer et al, 1996), insulin growth factor (IGF) (Duan et al, 1999), and the epidermal growth factor (EGF) family members (Ram and Ethier, 1996; Okano et al, 2000) are among those receptors. Akt- 1 has been found in correlation with higher expression of erbB-2 in a panel of breast cancer cell lines (Ahmad et al, 1999). A recent report showed that inhibition of this pathway with a monoclonal antibody against erbB-2 was not restricted to cells that overexpressed erbB-2 but also interfered with heregulin $\beta 1$ (HRG)-mediated activation in cells with basal levels of the receptor (Liu et al, 1999). The former indicates that both, overexpression of erbB-2 and stimulation with HRG could be able to trigger this pathway (Tan et al, 1999; Ignatoski et al, 2000).

Until the present, Akt isoforms has been found overexpressed in several tumour types (Staal, 1987; Bellacosa et al, 1995; Cheng et al, 1996; Ruggeri et al, 1998) but the information in breast cancer is limited. In the present study we analyzed the expression and activation of Akt-1 in relation to some factors involved in its pathway 
as well as other tumour characteristics. We also aimed to examine the significance of this protein for patient's survival after endocrine treatment.

\section{MATERIALS AND METHODS}

\section{Patients}

This study comprized 93 breast cancer patients (35-49 years) from the Southeast Sweden Health Care Region who underwent surgery between 1984 and 1996. All patients were treated with tamoxifen, goserelin or both endocrine modalities. The tumours were positive for ER or progesterone receptor (PgR) in $96 \%$ of the cases. The medium follow-up time among the disease-free patients was 64 months. The first relapse appeared 20 months after surgery and further on 22 patients (24\%) relapsed with distant metastasis. For this study we used frozen sections from tumours still available after hormone receptor assays. The material was stored at $-70^{\circ} \mathrm{C}$ until used.

\section{Determination of steroid receptors and S-phase fraction}

The levels of steroid hormones were measured using the EIA assay from Abbot (Lab. Diagnostic Division, Abbot Park, USA). Samples with ER or PgR $\geqslant 0.3 \mathrm{fmol} \mu \mathrm{g}^{-1}$ DNA were considered as positive. Likewise, DNA flow cytometry was performed in clinical routine practice to determine the S-phase fraction (SPF). A cut-off level of $10 \%$ was used to differentiate tumours with low and high SPF respectively. Both methods have been described previously (Stål et al, 1992)

\section{Flow cytometry to determine erbB-2 content}

This method was previously described (Stål et al, 1994). Fixation was carried out in $1 \%$ paraformaldehyde for $3 \mathrm{~min}$. The cells were incubated with the monoclonal antibody c-neu (Ab-2), clone 9G6 (Oncogene Science Inc., Manhasset, NY, USA) or an irrelevant isotype control antibody (Sigma Chemical Co., St Louis, MI, USA), both diluted in $\mathrm{PAB}$ at $1 \mu \mathrm{g} \mathrm{ml}^{-1}$. The secondary antibody rabbit-anti-mouse $\mathrm{F}(\mathrm{ab})_{2}$ conjugated with FITC (DAKO, Denmark) was added at a 1:50 dilution. Finally the cells were treated with RNAse, stained with propidium iodide and analyzed in a FACScan flow cytometer (Becton Dickinson, USA). A fluorescence index (FI) was calculated as the ratio between the geometrical mean of the fluorescence associated with the specific antibody and the negative control. Tumours with FI $\geqslant 2.0$ were considered as positive.

\section{Immunohistochemical detection}

The staining procedure followed a standard protocol. Imprints from nine tumours, otherwise frozen-sections $(5 \mathrm{~mm})$ were used for this purpose. Slides were fixed in acetone for $10 \mathrm{~min}$ at $4^{\circ} \mathrm{C}$; blocked in PBS-10\% swine serum (DAKO, Denmark) and incubated with the primary antibodies: a mouse monoclonal antibody, clone $124\left(3.5 \mu \mathrm{g} \mathrm{ml}^{-1}\right)$ (DAKO, Denmark) to detect Bcl-2; a sheep polyclonal antibody (at $8 \mu \mathrm{g} \mathrm{ml}^{-1}$ ) against the phosphorylated Ser residue in position 473 of human Akt1(Upstate Biotechnology; Lake Placid, NY, USA); and goat polyclonal antibodies against-HRG (at $0.5 \mu \mathrm{g} \mathrm{ml}^{-1}$ ) and Akt-1 (at $8 \mu \mathrm{g} \mathrm{ml}^{-1}$ ) respectively (Santa Cruz Biotechnology, Inc). The negative control, in case of Bcl-2, consisted of a mouse IgG1 kappa-Mopc 21 (Sigma Aldrich, Sweden) at a concentration of $8 \mu \mathrm{g} \mathrm{ml}^{-1}$ while the polyclonal antibodies were incubated with their respective neutralizing peptides. Incubation with primary antibodies was performed overnight at $4^{\circ} \mathrm{C}$ in a moisture chamber. As secondary antibody a swine multi-link IgG1 anti-goat/ mouse/rabbit conjugated with biotin and diluted 1:50 was employed, followed by streptavidin-horseradish peroxidase (DAKO, Denmark). Positive cells were visualized with 3.3-diaminobenzidin hydrochloride and the nuclei were counterstained with haematoxylin.

\section{Scoring}

Two independent observers evaluated the sections using a light microscopy Leica DM LS (Leica Microsystems; Wetzlar, Germany). In case of HRG, we analyzed the staining associated to malignant cells and the surrounding stromal cells (fibroblasts). Tumours were considered positive for the stromal reaction when $10 \%$ or more stained fibroblasts were observed. In this case the imprints were excluded for being unreliable. In the malignant population we considered intensity $(+$ or ++ ) and frequency: (a) 0 cells; (b) $1-$ $10 \%$ cells; (c) $>10-50 \%$ cells; and (d) $>50 \%$ of the cells being positive. The frequency and intensity were added to regroup the variable into three categories: (1) no reaction; (2) low reaction $(1-10 \% /+/++$ or $>10-50 \% /+) ;(3)$ strong reaction $(>10-$ $50 \% /++$ or staining in $>50 \% /+/++)$.

For Akt-1 and pAkt, the tumours were considered positive, independently of the frequency, when the brown colour observed in the cytoplasm of the cells was strong and clearly different from that of the negative control. For Bcl-2, a cut-off point of $\geqslant 10 \%$ was considered on the base of previous studies (Hellemans et al, 1995; Elledge et al, 1997).

\section{Peptide neutralization assay}

Blockade with synthetic peptides tested the specificity of the polyclonal antibodies. The highest working dilution for the antibodies was established as $2 \mu \mathrm{g} \mathrm{ml}^{-1}$ in case of pAkt and $0.5 \mu \mathrm{g} \mathrm{ml}^{-1}$ in case of HRG. To be neutralized, the antibodies were pre-incubated overnight at $4{ }^{\circ} \mathrm{C}$ with five and 10 times more peptide (for pAkt and HRG respectively) in a total volume of $100 \mu \mathrm{l}$ and centrifuged at $10000 \mathrm{~g}$. Supernatants were applied to the sections.

\section{Statistics}

The relationships between different variables were assessed by the Chi-square test or Chi-square test for trend, when required. The role of each variable (univariate analysis) or their joint effect (multivariate analysis) was evaluated with Cox's proportional hazard regression. The multiple sample test, which is a generalization of Gehan's generalized Wilcoxon test, was also used to test the significance in the survival analysis. All the procedures are comprised in the statistical package 'Statistica' (Statsoft, inc 1999 Statistica for Windows). The criterion for statistical significance was $P<0.05$

\section{RESULTS}

\section{Association of Akt-1 and pAkt with other variables}

The pattern of staining for Akt-1 is shown in Figure 1A. The protein was expressed in $46 \%$ of the tumours without significant correlation with any prognostic factor. On the other hand, pAkt, positive in $54 \%$ of the cases (Figure $1 \mathrm{~B}$ ), was positively correlated with the presence of HRG-expressing fibroblasts $(P=0.017)$ and inversely to the SPF $(P=0.001)$. No association was seen with nodal status, tumour size, ER, PgR, Bcl-2 or erbB-2 (Table 1). A moderate correlation, although statistically significant $(P=0.04)$, was found between Akt-1 and pAkt staining. Besides, HRG, observed in malignant cells, was negatively associated with lymph node status $(P=0.005)$ and with ER $(P=0.026)$. The controls consisting of peptide-blocked antibodies were negative in all cases (result not shown). 
542

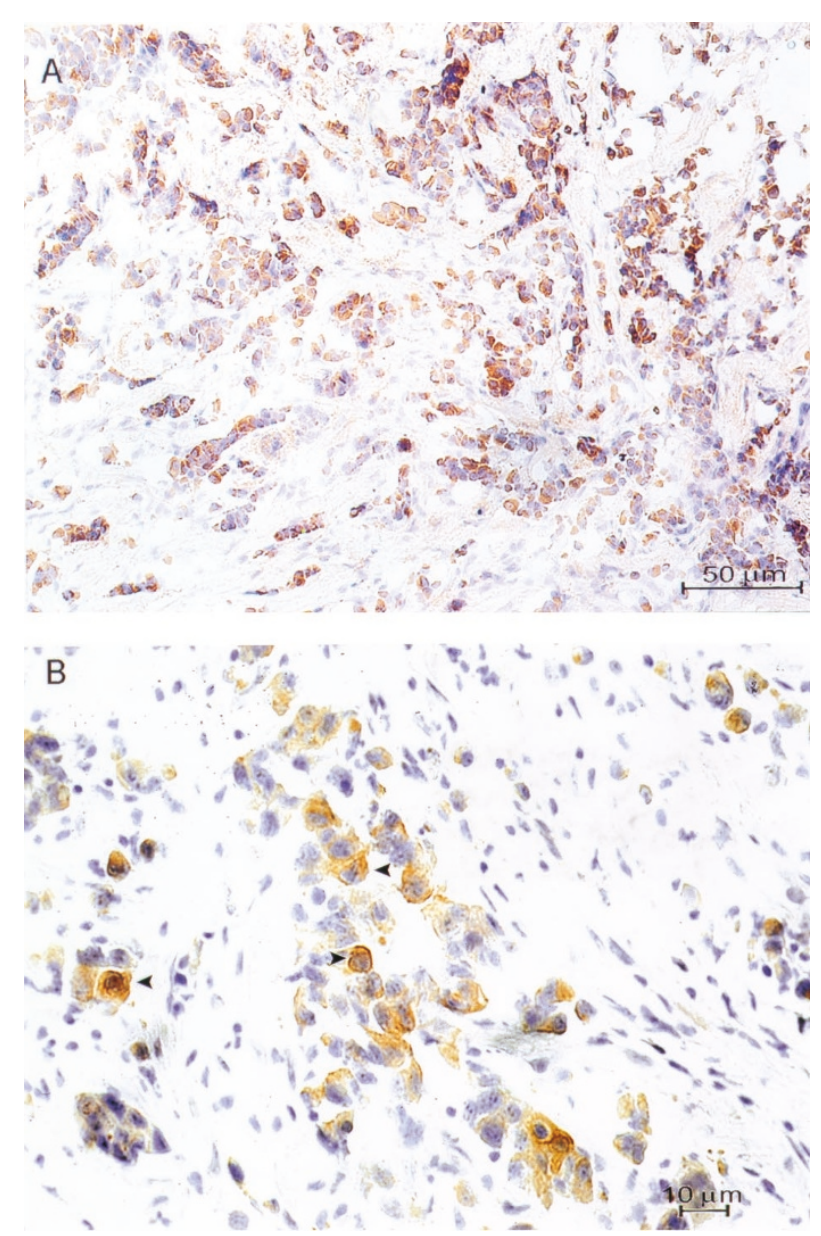

Figure I Representative immunostaining of Akt-I (A) $(200 \times)$ and pAkt (B) $(400 \times)$, note the arrowheads indicating positive staining in the cytoplasm of malignant cells.

\section{pAkt and other variables in relation to distant recurrence-free survival}

In univariate analysis neither HRG nor Akt-1 had prognostic value, while pAkt positivity predicted a higher risk of developing metastasis with borderline significance $(\mathrm{RR}=2.4,95 \% \mathrm{CI}, 1.0-6.2$ ) (see Figure 2A). Multivariate analysis, including pAkt and traditional prognostic factors, indicated that pAkt was an independent predictor of distant recurrence (Table 2). The risk in the pAkt+ group was higher (5.4) compared to the pAkt- group; $(P=0.004)$. Besides, the risk also increased significantly for the lymphonode positive patients $(P=0.0008)$ and for those with high SPF $(P=0.01)$.

The possible phenotypes of pAkt in combination with SPF are shown in Figure 2B. Patients with low SPF and pAkt negative tumour had a 6 year survival rate of $93 \%$ in comparison with $47 \%$ for those with high SPF and pAkt positive phenotype. The distant recurrence-free survival in relation to pAkt and nodal status is shown in Figure 2C. All patients in the double negative group (node-/pAkt-) remained alive after 6 years of follow-up while in the node+/pAkt+ group the distant recurrence-free survival rate fell to $59 \%$.

\section{DISCUSSION}

As far as we know this is the first immunohistochemical study analyzing the expression and activation of Akt in breast tumours in relation to other clinico-pathological variables and survival.

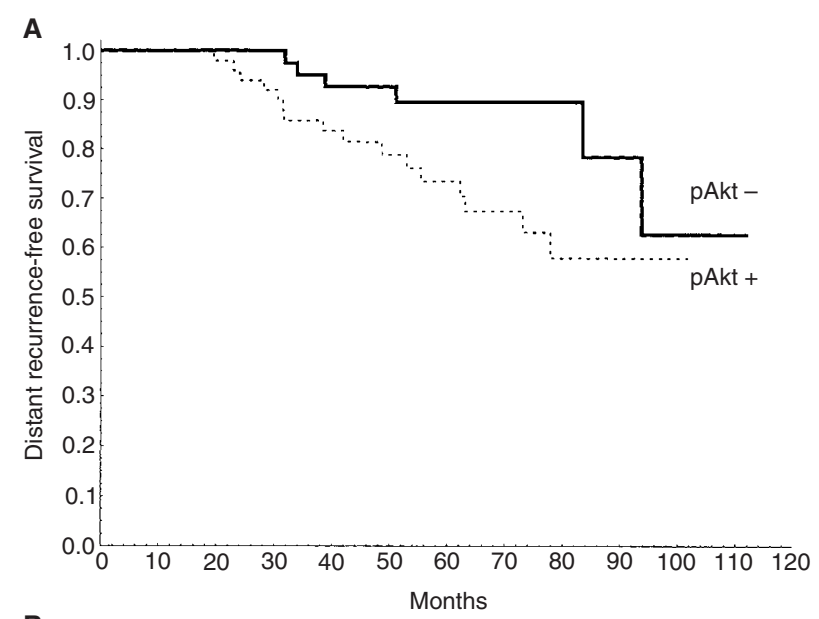

B

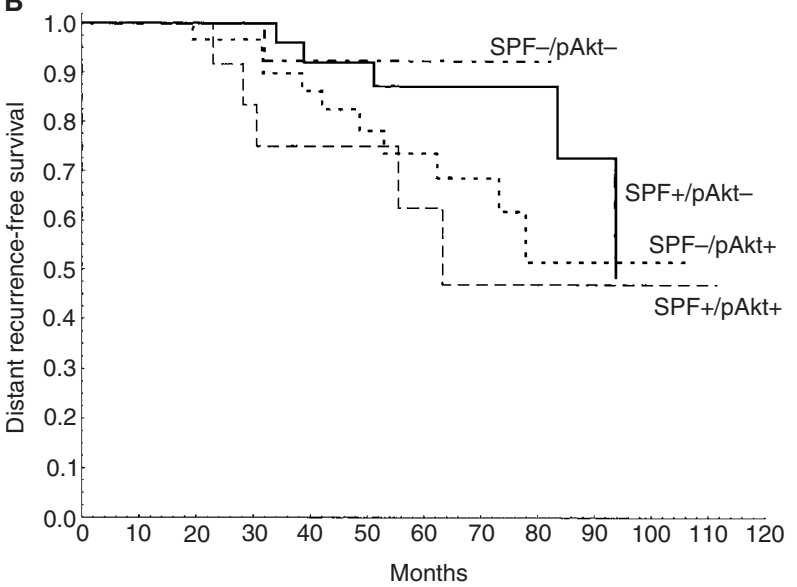

C

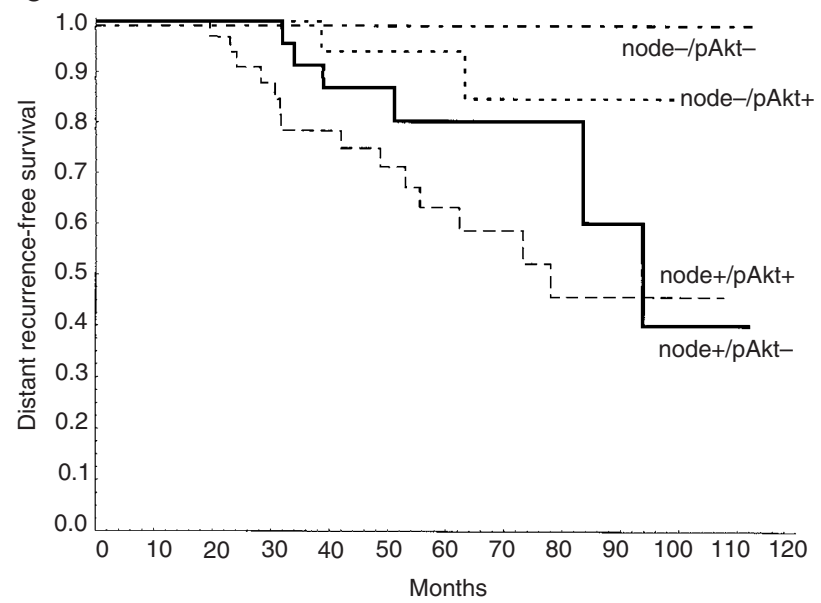

Figure 2 (A) Kaplan-Meier curves comparing survival among pAkt negative patients in comparison with pAkt positive group $(P=0.07$ by Cox proportional hazard model and $P=0.03$ by Gehan's generalized Wilcoxon test). (B) pAkt/SPF subgroups. The combined variable was scored as: 0 (SPF-/pAkt-); I (SPF+/pAkt-); 2 (SPF-/pAkt+); 3 (SPF+/pAkt+). According to this order, the risk of developing distant recurrence increased gradually with a rate ratio of 1.8 (Cox proportional hazard regression, $P=0.017$ ). Distant recurrence-free survival rates at 6 years were of 93 , 88,69 and $47 \%$ respectively for each subgroup. (C) Kaplan-Meier curves based on pAkt and nodal status. The combined variable was scored as: 0 (node-/pAkt-); I (node-/pAkt+); 2 (node+/pAkt-; 3 (node+/pAkt+). According to this order, the risk of developing distant recurrence increased gradually with a rate ratio of 2.5 (Cox proportional hazard regression $P=0.001$ ). Distant recurrence-free survival rates at 6 years were 100,85 , 81 and $59 \%$ respectively for each subgroup. In the lymph node negative group there were two recurrences; both belonged to pAkt+ subgroup. 
Table I Akt-I and pAkt in relation to other clinical data and tumour characteristics

\begin{tabular}{|c|c|c|c|c|c|c|}
\hline & $\begin{array}{c}\text { Akt-I - } \\
n \text { (\%) }\end{array}$ & $\begin{array}{c}\text { Akt-I+ } \\
n(\%)\end{array}$ & Significance & $\begin{array}{c}\text { pAkt-- } \\
n(\%)\end{array}$ & $\begin{array}{c}\text { pAkt+ } \\
\text { n (\%) }\end{array}$ & Significance \\
\hline \multicolumn{7}{|l|}{ Nodal status } \\
\hline- & $20(57)$ & $15(43)$ & \multirow[t]{2}{*}{$P=0.60$} & $18(5 \mid)$ & $17(49)$ & \multirow[t]{2}{*}{$P=0.43$} \\
\hline+ & $30(52)$ & $28(48)$ & & $25(43)$ & $33(57)$ & \\
\hline \multicolumn{7}{|l|}{ Tumour size } \\
\hline$<20 \mathrm{~mm}$ & $25(59)$ & $17(40)$ & \multirow[t]{2}{*}{$P=0.30$} & $17(59)$ & $25(4 I)$ & \multirow[t]{2}{*}{$P=0.30$} \\
\hline$\geqslant 20 \mathrm{~mm}$ & $25(49)$ & $26(5 \mathrm{I})$ & & $26(5 \mathrm{I})$ & $25(49)$ & \\
\hline \multicolumn{7}{|l|}{ ER } \\
\hline- & || (50) & II (50) & \multirow{2}{*}{$P=0.70$} & $13(59)$ & $9(4 I)$ & \multirow[t]{2}{*}{$P=0.16$} \\
\hline+ & $39(55)$ & $32(45)$ & & $30(42)$ & $41(58)$ & \\
\hline \multicolumn{7}{|l|}{ PgR } \\
\hline- & $4(57)$ & $3(43)$ & \multirow[t]{2}{*}{$P=0.85$} & $4(57)$ & $3(43)$ & \multirow[t]{2}{*}{$P=0.54$} \\
\hline+ & $46(53)$ & $40(47)$ & & $39(45)$ & $47(55)$ & \\
\hline \multicolumn{7}{|l|}{$\mathrm{SPF}^{\mathrm{a}}$} \\
\hline$<10 \%$ & $20(44)$ & $25(56)$ & \multirow[t]{2}{*}{$P=0.08$} & $15(33)$ & $30(67)$ & \multirow[t]{2}{*}{$P=0.001$} \\
\hline$\geqslant 10 \%$ & $23(64)$ & $13(36)$ & & $25(69)$ & $11(3 \mid)$ & \\
\hline \multicolumn{7}{|l|}{ erbB-2 } \\
\hline $\mathrm{Fl}<2.0$ & $48(55)$ & $39(45)$ & \multirow[t]{2}{*}{$P=0.30$} & $40(46)$ & $47(54)$ & \multirow[t]{2}{*}{$P=0.80$} \\
\hline $\mathrm{Fl} \geqslant 2.0$ & $2(33)$ & $4(67)$ & & $3(50)$ & $3(50)$ & \\
\hline \multicolumn{7}{|l|}{$\mathrm{BCl}-2$} \\
\hline- & $24(62)$ & $15(38)$ & \multirow[t]{2}{*}{$P=0.20$} & $17(44)$ & $22(56)$ & \multirow[t]{2}{*}{$P=0.60$} \\
\hline+ & $26(48)$ & $28(52)$ & & $26(48)$ & $28(52)$ & \\
\hline \multicolumn{7}{|c|}{$\mathrm{HRG} \beta$ | malignant cells ${ }^{\mathrm{b}}$} \\
\hline No & $17(59)$ & $12(4 \mid)$ & \multirow[t]{3}{*}{$P=0.90$} & $16(55)$ & $13(45)$ & \multirow[t]{3}{*}{$P=0.43$} \\
\hline Low & $17(44)$ & $22(56)$ & & $15(38)$ & $24(62)$ & \\
\hline High & $13(59)$ & $9(41)$ & & $10(45)$ & $12(55)$ & \\
\hline \multicolumn{7}{|c|}{ HRG $\beta$ | host cells ${ }^{c}$} \\
\hline$<10 \%$ & $31(60)$ & $21(40)$ & \multirow[t]{2}{*}{$P=0.15$} & $28(78)$ & $8(22)$ & \multirow[t]{2}{*}{$P=0.017$} \\
\hline$\geqslant 10 \%$ & $13(43)$ & $17(57)$ & & $24(52)$ & $22(48)$ & \\
\hline
\end{tabular}

a, b, cData from 12, 3 and II patients respectively is missing.

Table 2 Multivariate Cox proportional hazard regression to determine the predictive value of different variables in relation to distant recurrence. Data for all of the patients was available in 81 cases

\begin{tabular}{|c|c|c|}
\hline & Rate ratio $(95 \% \mathrm{Cl})$ & Significance \\
\hline \multicolumn{3}{|l|}{ Nodal status } \\
\hline- & 1.0 & \\
\hline+ & $13.9(2.9-63.1)$ & $P=0.008$ \\
\hline \multicolumn{3}{|l|}{ Tumour size } \\
\hline$<20 \mathrm{~mm}$ & 1.0 & \\
\hline$\geqslant 20 \mathrm{~mm}$ & $1.5(0.6-3.7)$ & $P=0.37$ \\
\hline \multicolumn{3}{|l|}{ ER } \\
\hline- & 1.0 & \\
\hline+ & $0.58(0.2-1.9)$ & $P=0.37$ \\
\hline \multicolumn{3}{|l|}{$\operatorname{PgR}$} \\
\hline- & 1.0 & \\
\hline+ & $0.9(0.2-5.4)$ & $P=0.93$ \\
\hline \multicolumn{3}{|l|}{ SPF } \\
\hline$<10 \%$ & 1.0 & \\
\hline$\geqslant 10 \%$ & $3.9(1.4-10.7)$ & $P=0.01$ \\
\hline \multicolumn{3}{|l|}{ pAkt } \\
\hline- & 1.0 & \\
\hline+ & $5.4(1.7-\mid 7.1)$ & $P=0.004$ \\
\hline
\end{tabular}

We aimed to examine whether this protein, found in vitro to play a prominent role in oncogenesis (Kandel and Hay, 1999) and possibly in tamoxifen resistance (Campbell et al, 2001), showed the same significance in clinical material.

In this study, Akt-1 was considered positive in $46 \%$ of the tumours but it was not associated with any other prognostic marker. The variable did not provide any new information regard- ing the survival of the patients. Despite a positive correlation between Akt-1 and the activated protein, some Akt-1 negative cases resulted as pAkt positive. This paradox may be explained by either different sensitivity of the antibodies or by crossreactivity of the phospho-Akt-1 (ser473) antibody with another activated isoform present in the tumour, like Akt-2 or Akt-3. Otherwise, the pattern of staining with both antibodies was similar, being the phosphorylated protein localized to some extent to the cell membrane and mainly observed in the cytoplasm of the malignant cells. Albeit the activation of Akt is generally associated with its translocation from the cytosol to the plasma membrane by virtue of its pleckstrin homology (PH) domain (Andjelkovic et al, 1997), it is possible for Akt lacking a $\mathrm{PH}$ domain to be activated without being localized to this cell compartment (Sable et al, 1998).

As in case of Akt-1, we could not find any significant association of pAkt with nodal status, tumour size, ER, PgR or Bcl-2 but we did find a strong negative association with SPF. Since the activation of Akt promotes cell cycle progression by modulating the expression (Brennan et al, 1997; Muise-Helmericks et al, 1998) and stabilization of cyclin D1 (Graff et al, 2000) and the SPF is an indicator of the proliferative state of the cells, the negative association between pAkt and SPF was unexpected. Nevertheless, an increase in cyclin D1 does not always lead to cell cycle progression (Hiyama et al, 1997; Mitsuuchi et al, 2000), and in some cases the expression of cyclin D1 has been associated with low proliferative rate in clinical material (Nielsen et al, 1999). Furthermore, the survival analysis indicated that patients in the pAkt positive group tended to have a higher risk to develop distant recurrence compared to the negative group, and the multivariate analysis showed that pAkt was an independent prognostic factor in addition to nodal status and SPF. The analysis of the interaction between pAkt and SPF revealed that a low SPF was a favourable feature only if the tumour 
was in addition pAkt negative. This suggests that pAkt could be indicative of distant relapses in spite of a low proliferative state of the tumour, probably by promoting cell survival rather than cell proliferation.

In a previous report, including 20 adenocarcinomas, a significant association was found between the expression of erbB-2 and pAkt (Zhou et al, 2000). In the present study we found no significant association of erbB-2 with Akt-1 or with pAkt. We consider that our study could be undersized to detect significant differences, since only $7 \%$ of the tumours overexpressed the receptor $(n=6)$ as expected in a sample conformed mostly by ER or PgR positive tumours. Therefore a larger material might help to confirm this relationship but also it may be interesting to address this question in the context of other EGF family members such as erbB-3, 4 and EGFR.

In this study we also explored the ligand HRG. The protein can be present in the cytoplasm of both malignant and stromal cells. While in a previous report, the host-derived HRG correlated with aggressive clinical behaviour (Visscher et al, 1997) we did not find the same result in our study. However we found a positive correlation between host-derived HRG and pAkt. It is known that the breast stroma plays an important role in breast epithelial growth and differentiation. Besides, tumour-associated fibroblasts have been found to confer morphogenic and mitogenic induction of epithelial cells (Shekhar et al, 2001) and to induce acceleration of epithelial tumour growth in vivo (Camps et al, 1990) supporting the role of host cells as source of paracrine signals that may not only affect cell growth but also turn on survival pathways, like Akt.

On the other hand, in those tumours where HRG was found in the malignant cells the patients less often showed evidence of lymphonodal spread in line with the results of Bacus et al (1994). The negative association found with ER status still could implicate this factor with an aggressive phenotype, although the

\section{REFERENCES}

Aguilar Z, Akita RW, Finn RS, Ramos BL, Pegram MD, Kabbinavar FF, Pietras RJ, Pisacane P, Sliwkowski MX, Slamon DJ (1999) Biologic effects of heregulin/neu differentiation factor on normal and malignant human breast and ovarian epithelial cells. Oncogene 18: 6050-6062

Ahmad S, Singh N, Glazer RI (1999) Role of AKT1 in 17beta-estradiol- and insulin-like growth factor I (IGF-I)-dependent proliferation and prevention of apoptosis in MCF-7 breast carcinoma cells. Biochem Pharmacol 58: $425-430$

Ahmed NN, Franke TF, Bellacosa A, Datta K, Gonzalez-Portal ME, Taguchi T, Testa JR, Tsichlis PN (1993) The proteins encoded by c-akt and v-akt differ in post-translational modification, subcellular localization and oncogenic potential. Oncogene 8: 1957-1963

Andjelkovic M, Alessi DR, Meier R, Fernandez A, Lamb NJ, Frech M, Cron P, Cohen P, Lucocq JM, Hemmings BA (1997) Role of translocation in the activation and function of protein kinase B. J Biol Chem 272: 31515-31524

Bacus SS, Gudkov AV, Zelnick CR, Chin D, Stern R, Stancovski I, Peles E, Ben-Baruch N, Farbstein H, Lupu R, Wen D, Sela M, Yarden Y (1993) Neu differentiation factor (heregulin) induces expression of intercellular adhesion molecule 1: implications for mammary tumors. Cancer Res 53: $5251-5261$

Bacus SS, Zelnick CR, Plowman G, Yarden Y (1994) Expression of the erbB-2 family of growth factor receptors and their ligands in breast cancers. Implication for tumor biology and clinical behavior. Am J Clin Pathol 102: S13S24

Bellacosa A, de Feo D, Godwin AK, Bell DW, Cheng JQ, Altomare DA, Wan M, Dubeau L, Scambia G, Masciullo V, Ferrandina G, Panici BP, Mancuso S, Neri G, Testa JR (1995) Molecular alterations of the AKT2 oncogene in ovarian and breast carcinomas. Int J Cancer 64: 280-285

Brennan P, Babbage JW, Burgering BM, Groner B, Reif K, Cantrell DA (1997) Phosphatidylinositol 3-kinase couples the interleukin-2 receptor to the cell cycle regulator E2F. Immunity 7: 679-689 risk to develop distant metastasis was not higher among the patients with high expression of HRG. A possible interaction with nodal status is not excluded since among the node positive patients the recurrence rate tended to be higher in cases of high HRG expression (result not shown). Nevertheless the role of HRG in vivo remains to be explained. This factor has been associated in vitro with induction of cell proliferation (Holmes et al, 1992; Aguilar et al, 1999), invasion (Hijazi et al, 2000), apoptosis (Daly et al, 1997), differentiation (Peles et al, 1992; Bacus et al, 1993) and inhibition of cell proliferation (Hamburger and Yoo, 1997; Xu et al, 1997).

We conclude that the activation of Akt could be a factor to consider together with S-phase fraction and nodal status in predicting distant relapses of breast cancer. However it remains to be elucidated which isoform plays the principal role. The shorter disease-free survival associated with the pAkt positive phenotype in this series of endocrine treated patients, may indicate a link between this pathway and treatment failure but further studies based on randomized trials are needed to validate this hypothesis.

\section{ACKNOWLEDGEMENTS}

This work was supported by grants from the Swedish Cancer Society and the Research Council of Southeast Sweden.

Members of the Southeast Sweden Breast Cancer Group LG Arnesson, A Malmström, B Nordenskjöld, K Nordenskjöld, (Linköping), H Bång (Motala), A Ch Källström (Norrköping), E Einarsson (Eksjö), B Norberg (Jönköping), P Skoog (Värnamo), A Henning (Oskarshamn), M Sundquist (Kalmar), G Tejler (Västervik).
Campbell RA, Bhat-Nakshatri P, Patel NM, Constantinidou D, Ali S, Nakshatri H (2001) Phosphatidylinositol 3-kinase/AKT-mediated activation of estrogen receptor alpha: a new model for anti-estrogen resistance. J Biol Chem 276: 9817 - 9824

Camps JL, Chang SM, Hsu TC, Freeman MR, Hong SJ, Zhau HE, von Eschenbach AC, Chung LW (1990) Fibroblast-mediated acceleration of human epithelial tumor growth in vivo. Proc Natl Acad Sci USA 87: $75-79$

Cheng JQ, Ruggeri B, Klein WM, Sonoda G, Altomare DA, Watson DK, Testa JR (1996) Amplification of AKT2 in human pancreatic cells and inhibition of AKT2 expression and tumorigenicity by antisense RNA. Proc Natl Acad Sci USA 93: $3636-3641$

Clarke R, Leonessa F, Welch JN, Skaar TC (2001) Cellular and molecular pharmacology of antiestrogen action and resistance. Pharmacol Rev 53: $25-71$

Coffer PJ, Jin J, Woodgett JR (1998) Protein kinase B (c-Akt): a multifunctional mediator of phosphatidylinositol 3-kinase activation. Biochem 335: $1-13$

Daly JM, Jannot CB, Beerli RR, Graus-Porta D, Maurer FG, Hynes NE (1997) Neu differentiation factor induces ErbB2 down-regulation and apoptosis of ErbB2-overexpressing breast tumor cells. Cancer Res 57: 3804-3811

Duan C, Liimatta MB, Bottum OL (1999) Insulin-like growth factor (IGF)-I regulates IGF-binding protein-5 gene expression through the phosphatidylinositol 3-kinase, protein kinase B/Akt, and p70 S6 kinase signaling pathway. J Biol Chem 274: 37147-37153

Elledge RM, Green S, Howes L, Clark GM, Berardo M, Allred DC, Pugh R, Ciocca D, Ravdin P, O’Sullivan J, Rivkin S, Martino S, Osborne CK (1997) bcl-2, p53, and response to tamoxifen in estrogen receptor-positive metastatic breast cancer: a Southwest Oncology Group study. J Clin Oncol 15: $1916-1922$ 
Graff JR, Konicek BW, McNulty AM, Wang Z, Houck K, Allen S, Paul JD, Hbaiu A, Goode RG, Sandusky GE, Vessella RL, Neubauer BL (2000) Increased AKT activity contributes to prostate cancer progression by dramatically accelerating prostate tumor growth and diminishing p27Kipl expression. J Biol Chem 275: 24500-24505

Hamburger AW, Yoo JY (1997) Phosphatidylinositol 3-kinase mediates heregulin-induced growth inhibition in human epithelial cells. Anticancer Res 17: $2197-2200$

Hellemans P, van Dam PA, Weyler J, van Oosterom AT, Buytaert P, Van Marck E (1995) Prognostic value of bcl-2 expression in invasive breast cancer. Br J Cancer 72: $354-360$

Hijazi MM, Thompson EW, Tang C, Coopman P, Torri JA, Yang D, Mueller SC, Lupu R (2000) Heregulin regulates the actin cytoskeleton and promotes invasive properties in breast cancer cell lines. Int J Oncol 17: $629-641$

Hiyama H, Iavarone A, LaBaer J, Reeves SA (1997) Regulated ectopic expression of cyclin D1 induces transcriptional activation of the cdk inhibitor p21 gene without altering cell cycle progression. Oncogene 14: 2533-2542

Holmes WE, Sliwkowski MX, Akita RW, Henzel WJ, Lee J, Park JW, Yansura D, Abadi N, Raab H, Lewis GD, Shepard HM, Kuang JW, Wood WI, Goeddel DV, Vandlen RL (1992) Identification of heregulin, a specific activator of p185erbB2. Science 256: $1205-1210$

Ignatoski KM, Maehama T, Markwart SM, Dixon JE, Livant DL, Ethier SP (2000) ERBB-2 overexpression confers PI 3' kinase-dependent invasion capacity on human mammary epithelial cells. Br J Cancer 82: 666-674

Imai A, Tamaya T (2000) GnRH receptor and apoptotic signaling. Vitam Horm 59: $1-33$

Kandel ES, Hay N (1999) The regulation and activities of the multifunctional serine/threonine kinase Akt/PKB. Exp Cell Res 253: 210-229

Klinghoffer RA, Duckworth B, Valius M, Cantley L, Kazlauskas A (1996) Platelet-derived growth factor-dependent activation of phosphatidylinositol 3-kinase is regulated by receptor binding of SH2-domain-containing proteins which influence Ras activity. Mol Cell Biol 16: 5905-5914

Liu W, Li J, Roth RA (1999) Heregulin regulation of Akt/protein kinase B in breast cancer cells. Biochem Biophys Res Commun 261: 897-903

MacGregor JI, Jordan VC (1998) Basic guide to the mechanisms of antiestrogen action. Pharmacol Rev 50: 151-196

Michaud LB, Buzdar AU (2000) Complete estrogen blockade for the treatment of metastatic and early stage breast cancer. Drugs Aging 16: 261-271

Mitsuuchi Y, Johnson SW, Selvakumaran M, Williams SJ, Hamilton TC, Testa JR (2000) The phosphatidylinositol 3-kinase/AKT signal transduction pathway plays a critical role in the expression of p21WAF1/CIP1/ SDI1 induced by cisplatin and paclitaxel. Cancer Res 60: $5390-5394$

Muise-Helmericks RC, Grimes HL, Bellacosa A, Malstrom SE, Tsichlis PN, Rosen N (1998) Cyclin D expression is controlled post-transcriptionally via a phosphatidylinositol 3-kinase/Akt-dependent pathway. J Biol Chem 273: $29864-29872$

Nielsen NH, Loden M, Cajander J, Emdin SO, Landberg G (1999) G1-S transition defects occur in most breast cancers and predict outcome. Breast Cancer Res Treat 56: 105-112

Okano J, Gaslightwala I, Birnbaum MJ, Rustgi AK, Nakagawa H (2000) Akt/ Protein kinase B isoforms are differentially regulated by epidermal growth factor stimulation. J Biol Chem 275: 30934-30942
Peles E, Bacus SS, Koski RA, Lu HS, Wen D, Ogden SG, Levy RB, Yarden Y (1992) Isolation of the neu/HER-2 stimulatory ligand: a 44 kd glycoprotein that induces differentiation of mammary tumor cells. Cell 69: 205216

Perry RR, Kang Y, Greaves B (1995) Effects of tamoxifen on growth and apoptosis of estrogen-dependent and -independent human breast cancer cells. Ann Surg Oncol 2: 238-245

Ram TG, Ethier SP (1996) Phosphatidylinositol 3-kinase recruitment by p185erbB-2 and erbB-3 is potently induced by neu differentiation factor/ heregulin during mitogenesis and is constitutively elevated in growth factor-independent breast carcinoma cells with c-erbB-2 gene amplification. Cell Growth Differ 7: 551-561

Ruggeri BA, Huang L, Wood M, Cheng JQ, Testa JR (1998) Amplification and overexpression of the AKT2 oncogene in a subset of human pancreatic ductal adenocarcinomas. Mol Carcinog 21: 81-86

Sable CL, Filippa N, Filloux C, Hemmings BA, Van Obberghen E (1998) Involvement of the pleckstrin homology domain in the insulin-stimulated activation of protein kinase B. J Biol Chem 273: 29600-29606

Shekhar MP, Werdell J, Santner SJ, Pauley RJ, Tait L (2001) Breast stroma plays a dominant regulatory role in breast epithelial growth and differentiation: implications for tumor development and progression. Cancer Res 61: $1320-1326$

Staal SP (1987) Molecular cloning of the akt oncogene and its human homologues AKT1 and AKT2: amplification of AKT1 in a primary human gastric adenocarcinoma. Proc Natl Acad Sci USA 84: 5034-5037

Stål O, Brisfors A, Carstensen J, Ferraud L, Hatschek T, Nordenskjold B (1992) Relationships of DNA ploidy, S-phase fraction and hormone receptor status to tumor stage in breast cancers detected by population screening. The South-East Sweden Breast Cancer Group. Int J Cancer 51: $28-33$

Stål O, Sullivan S, Sun XF, Wingren S, Nordenskjold B (1994) Simultaneous analysis of c-erbB-2 expression and DNA content in breast cancer using flow cytometry. Cytometry 16: $160-168$

Tan M, Grijalva R, Yu D (1999) Heregulin beta1-activated phosphatidylinositol 3-kinase enhances aggregation of MCF-7 breast cancer cells independent of extracellular signal-regulated kinase. Cancer Res 59: $1620-1625$

Visscher DW, Sarkar FH, Kasunic TC, Reddy KB (1997) Clinicopathologic analysis of amphiregulin and heregulin immunostaining in breast neoplasia. Breast Cancer Res Treat 45: $75-80$

Xu FJ, Stack S, Boyer C, O’Briant K, Whitaker R, Mills GB, Yu YH, Bast Jr RC (1997) Heregulin and agonistic anti-p185(c-erbB2) antibodies inhibit proliferation but increase invasiveness of breast cancer cells that overexpress p185(c-erbB2): increased invasiveness may contribute to poor prognosis. Clin Cancer Res 3: 1629-1634

Zhou BP, Hu MC, Miller SA, Yu Z, Xia W, Lin SY, Hung MC (2000) HER-2/ neu blocks tumor necrosis factor-induced apoptosis via the Akt/NFkappaB pathway. J Biol Chem 275: 8027-8031 